\title{
A Tér és Társadalom 2014-ben
}

\author{
Space and Society in 2014
}

\section{CZIRFUSZ MÁRTON, TAGAI GERGELY}

\begin{abstract}
CZIRFUSZ Márton: tudományos munkatárs, MTA Közgazdaság- és Regionális Tudományi Kutatóközpont, Regionális Kutatások Intézete, Budapest; czirfusz@rkk.hu TAGAI Gergely: tudományos munkatárs, MTA Közgazdaság- és Regionális Tudományi Kutatóközpont, Regionális Kutatások Intézete, Budapest; tagai@rkk.hu
\end{abstract}

\begin{abstract}
Márton CZIRFUSZ: research fellow, Institute for Regional Studies, Centre for Economic and Regional Studies, Hungarian Academy of Sciences, Budapest; czirfusz@rkk.hu

Gergely TAGAI: research fellow, Institute for Regional Studies, Centre for Economic and Regional Studies, Hungarian Academy of Sciences, Budapest; tagai@rkk.hu
\end{abstract}

A korábbi években megjelent beszámolókhoz hasonlóan a 2014. évre is elkészítettük összeállításunkat a Tér és Társadalomban publikáló szerzőkről, valamint a 2014-ben a beérkezett tanulmányokat véleményező lektorokról.

\section{A folyóirat szerzői 2014-ben}

2014-ben 58 tanulmány, ismertető vagy beszámoló jelent meg a Tér és Társadalomban 84 szerző tollából. A folyóiratban publikáló szerzők száma a korábbi évekhez képest emelkedett, az olvasók többször találkozhattak szerzőpárosok és nagyobb szerzői kollektívák cikkeivel. Az utóbbi években szerzőink több mint fele különböző hazai egyetemek és főiskolák munkatársai közül került ki. Nem volt ez másképp tavaly sem, amikor 44 felsőoktatási intézményben dolgozó szerző különböző írásait olvashattuk. Önmagában a legnagyobb arányt továbbra is az MTA KRTK Regionális Kutatások Intézete képviseli, 2014-ben 20 munkatársunknak jelent meg tanulmánya vagy rövidebb beszámolója az intézet hivatalos lapjában. Emellett nagyobb számban jelentek meg publikációk a Tér és Társadalom hasábjain az MTA KRTK más kutatóintézeteiben dolgozó szerzőktől és az állami szférában alkalmazott kutatóktól, elemzőktől. Néhány fővel a magánszféra, a civil szféra és egyéb kutatóintézetek alkalmazottai is képviseltették magukat szerzőink között.

A Tér és Társadalom szerzői 2014-ben is - hasonlóan a korábbi évek tendenciáihoz - elsősorban Budapestről, valamint a vidéki kutatóközpontokból,

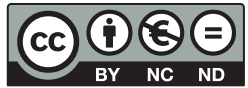


egyetemekről kerültek ki, és ha lehet, térbeli koncentrációjuk tovább is emelkedett a tavalyi év során. Budapest felsőoktatási intézményei, kutatóintézetei és állami hivatalai a folyóirat szerzőinek immár több mint 40\%-át adták (1. ábra). Pécsről, a Regionális Kutatások Intézetéből, illetve egyetemi kutatóhelyekről 16 kolléga jelent meg tanulmánnyal a TéT-ben, míg Győrből 14 szerző került ki - legtöbben a győri járműipari körzetről szóló tematikus számban. Egyéb vidéki kutatóhelyek közül Szeged, Gödöllő, Debrecen és Kaposvár adott még több szerzőt a folyóiratnak 2014-ben, de emellett Székesfehérvárról, Miskolcról, Békéscsabáról és Szarvasról is kaptunk tanulmányokat a tavalyi évben. Sajnos az az utóbbi években stabilizálódott trend, hogy külföldi (és külföldön dolgozó magyar) szerzők tanulmányai is rendre helyet kapjanak a Tér és Társadalomban, 2014-ben nem folytatódott. Tavaly kizárólag magyarországi szerzők jelentek meg írásaikkal a folyóiratban, így a szerkesztőség által felvállalt nemzetközi nyitás némileg megtorpant.

A korábbi évekhez képest jelentősebb átrendeződést lehetett megfigyelni 2014-ben a szerzők tudományterületi besorolása tekintetében. Tavaly szerzőink 40 százalékát (34 fö) sorolhattuk a regionális tudományt képviselők közé. Intézményi, akadémiai köztestületi hovatartozása alapján 18 szerzőnk közgazdaságtudományi kötődésű volt, míg tízen érkeztek a társadalomföldrajz szakterületéről. Az utóbbi évekhez képest nemcsak a regionalista kutatók arányának erősödését és a közgazdaságtudomány és a társadalomföldrajz szerzői arányai-

1. ábra: A Tér és Társadalom szerzőinek (munkahely szerinti) területi megoszlása, 2014 Spatial distribution of Space and Society's authors (according to workplace), 2014

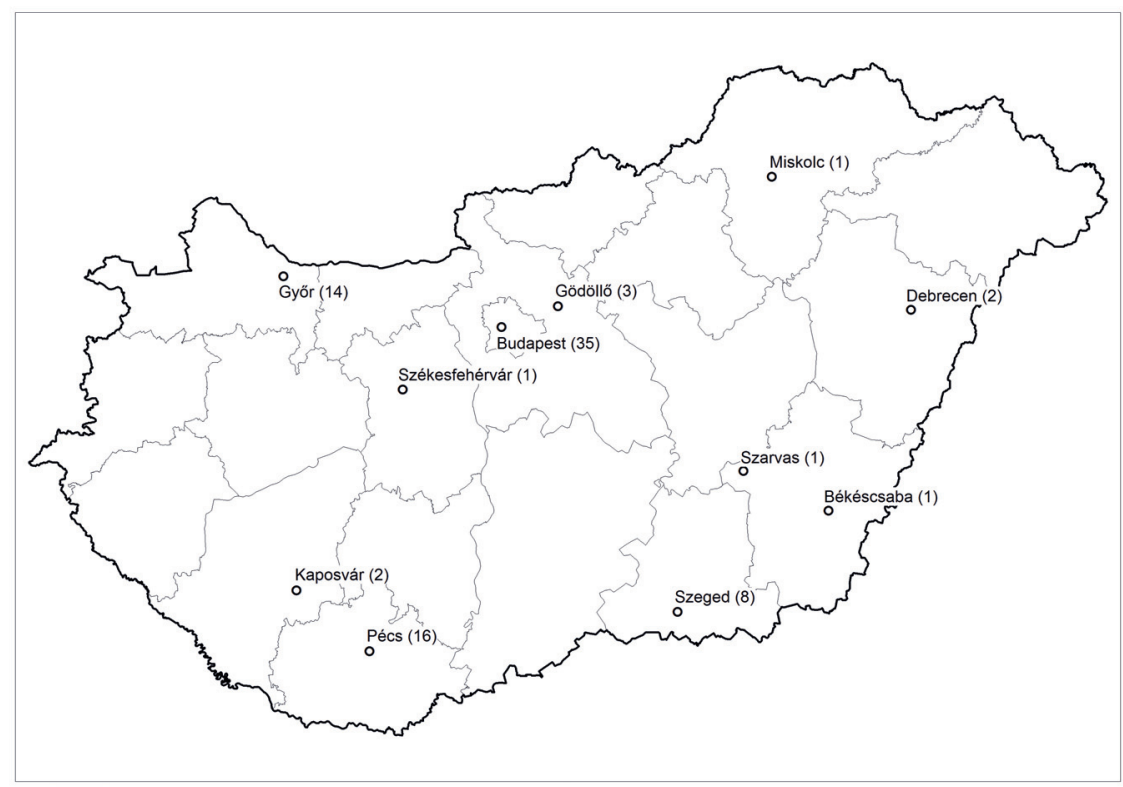


1. táblázat: A Tér és Társadalom szerzői és lektorai 2012-2014 Authors and reviewers of Space and Society 2012-2014

\begin{tabular}{lcc}
\hline & Szerzók & Lektorok \\
\hline Mindhárom év & 8 & 10 \\
Két év & 21 & 40 \\
2012 és 2013 & 9 & 17 \\
2012 és 2014 & 8 & 12 \\
2013 és 2014 & 4 & 11 \\
Egy év & 162 & 88 \\
2012 & 47 & 23 \\
2013 & 51 & 35 \\
2014 & 64 & 30 \\
\hline Összesen & 191 & 138 \\
\hline
\end{tabular}

nak megfordulását lehetett megfigyelni 2014-ben. Némileg szúkült az a szakterületi spektrum, amelynek képviselőit sikerrel szólítottuk meg. Ugyan az olyan tudományterületek, mint a szociológia, a statisztika vagy a környezettudomány tavaly is több szerzőt adtak a Tér és Társadalomnak, azonban további társtudományok irányába nemigen bővült a szerzők köre. Örömteli viszont, hogy szakmai nyitásunk elérte a természetföldrajz szakterületén dolgozó kutatókat is, akik diszciplínákon átívelő együttműködéseken keresztül jelenhettek meg a folyóiratban.

2012 és 2014 között majd kétszáz szerző publikált tanulmányt vagy rövidebb írást a Tér és Társadalomban (1. táblázat). Szerzőink nagyon kis hányadának (8 fö) jelent meg publikációja mindhárom évben, és alig több mint húsz olyan kutató akadt, akit ezen időszak alatt két alkalommal is szerzőink között tudhattunk. Szerzőink döntő többsége csak egyetlen adott évben jelent meg a folyóiratban. Sokukat hosszabb idő után visszatérő szerzőként üdvözölhettük, de évről évre bukkannak fel újabb nevek a szerzői névsorokban (fiatal kollégák vagy a tágabban vett társtudományok területéről érkező szerzők), akik még nem publikáltak a folyóiratban, most viszont sikerült őket is megszólítanunk.

2014-ben a következő személyek írásai jelentek meg a folyóiratban:

Baji Péter
Balázs Bálint
Bálint Lajos
Baranyi Béla
Baráth Gabriella
Benedek Zsófia
Berkes Judit
Bodnár Gábor
Bodor Ákos

Baji Péter

Bálint Lajos

Baranyi Béla

Baráth Gabriella

Benedek Zsófia

Bodnár Gábor

Bodor Ákos

Boros Lajos
Bozsonyi Károly
Czakó Katalin
Czikoráné Balázs Erika
Czirfusz Márton
Csanádi Mária
Csizmadia Zoltán
Daróczi Gergely
Egri Zoltán

Egyed Ildikó

Elekes Zoltán

Erdősi Ferenc

Faragó László

Farkas Máté

Fehér Katalin

Fekete Dávid

Földi Zsuzsa

Gergely Júlia 


\begin{tabular}{lll} 
Grünhut Zoltán & Lukovics Miklós & Sik András \\
Gyuris Ferenc & Lux Gábor & Simai Mihály \\
Hardi Tamás & Málovics György & Somlyódyné Pfeil Edit \\
Hopkó Iván & Mihók Barbara & Szabó Pál \\
Horváth Gyula & Molnár Ernő & Szabó Dániel Róbert \\
Horváth Anikó & Molnár Melinda & Szentistványi István \\
Horváth Péter & Nagy Zsófia & Szontágh Krisztina \\
Imre Gabriella & Nemes Nagy József & Tagai Gergely \\
Jakobi Ákos & Neszmélyi György Iván & Tipold Ferenc \\
Józsa Viktória & Nyakas Szabolcs & Tóth Gergely \\
Karácsonyi Dávid & Páger Balázs & Törőcsik Mária \\
Komlósi Éva & Pálmai Zsolt & Uszkai Andrea \\
Konczosné Szombathelyi & Pataki György & Uzzoli Annamária \\
\multicolumn{1}{c}{ Márta } & Páthy Ádám & Virág Tünde \\
Koppány Krisztián & Perge Kinga & Völgyi Katalin \\
Kovács Sándor Zsolt & Rácz Szilárd & Zuti Bence \\
Kovács Norbert & Rechnitzer János & Zsibók Zsuzsanna \\
László Péter & Roboz Ágnes & Zsom Brigitta \\
Lengyel Balázs & Sarudi Csaba & \\
Lukács Eszter & Sebestyénné Szép Tekla &
\end{tabular}

\section{A folyóirat lektorai 2014-ben}

A folyóirat magas és a szakma által elismert színvonalának biztosításában a beérkező írások lektorainak roppant fontos szerepe van. Alapos munkájuk segíti szerzőinket tanulmányuk tartalmának pontosításában, a szerkesztőség számára pedig azt a garanciát nyújtják, hogy szakmánk legkiválóbb írásai jelenhessenek meg a lapban.

A lektorok kiválasztásában 2014-ben is a regionális tudomány bázisintézményére, az MTA KRTK Regionális Kutatások Intézetére (RKI) támaszkodtunk (20 fö), emellett egyetemeken és főiskolákon alkalmazásban álló kollégáink szerepe sem elhanyagolható (23 fö). Amellett, hogy az RKI kutatói lektori vélemények írásával is elkötelezettek az intézet által fenntartott folyóirat iránt, a szerkesztőség számára általában jobban ismert kutatói munkásságuk, így sürübben kérjük fel őket. Stabilizálódott az a trend, hogy az MTA KRTK Közgazdaság-tudományi Intézetének és Világgazdasági Intézetének kutatóit felkérjük lektorálásra (2014-ben összesen 6 fö). A TéT interdiszciplináris jellegéből adódóan más MTA-intézetek (MTA TK Szociológiai, valamint az MTA CsFK Földrajztudományi Intézet) dolgozói is bíráltak írásokat (szintén 6 fó), illetve továbbra is keressük más kutatóhelyek, a magánszféra és az államigazgatás szakértőit egy-egy tanulmány értékelésére.

A 63 lektor területi megoszlásában (2. ábra) némileg mérséklődött a budapesti túlsúly az előzó évhez képest: a lektorok 51\%-a budapesti munkahelyen 
2. ábra: A Tér és Társadalom lektorainak (munkahely szerinti) területi megoszlása, 2014 Spatial distribution of Space and Society's reviewers (according to workplace), 2014

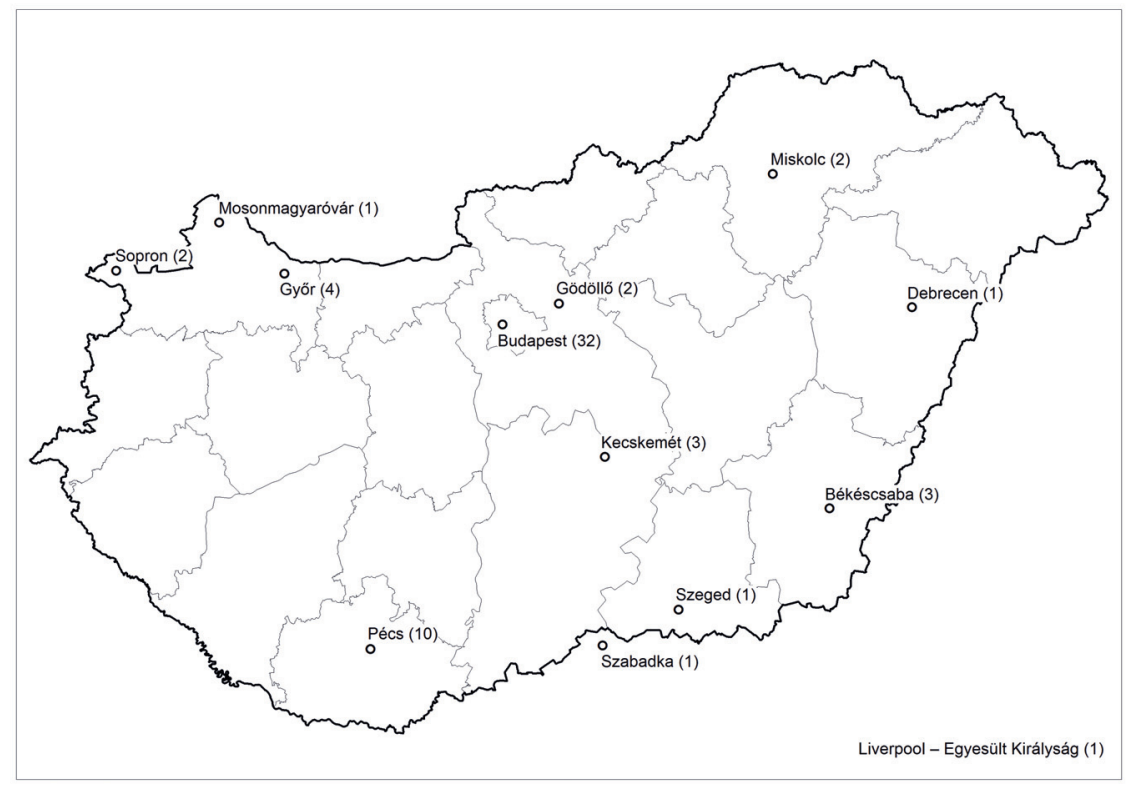

dolgozik, ezután Pécs következik 16\%-kal. 3-5 fö lektorált békéscsabai, kecskeméti (MTA KRTK RKI) és győri (RKI és egyetem) kollégáink közül, esetenként határon túl élő szakértőket is felkértünk.

Évek óta törekszünk arra, hogy a pályájuk elején levő tehetséges fiatal kutatókat is lépésről lépésre bevonjunk a lektorálásba - a 2014. évi lektorok ötöde nem volt idősebb 35 évnél. A tematikus számoknál bevált és a tavalyi évben is folytatódott a gyakorlat, hogy a teljes lapszámot ugyanaz a két lektor értékeli.

Ha a 2012 és 2014 közötti összesített adatokat vizsgáljuk (1. táblázat), összesen 138-an lektoráltak kéziratokat a folyóirat számára. Bár számíthatunk egy lektori „magra”, akik évről évre véleményeznek beérkező tanulmányokat (10-en mindhárom évben írtak lektori véleményt a folyóirat számára), ez az érték a 2011-2013-as évek magasabb, 18 fös értékéhez képest jól mutatja a lektori kör bővülését. 2014-ben 30 olyan lektort üdvözölhettünk, akik az ezt megelőző két évben nem készítettek bírálatot.

A Tér és Társadalom angol nyelvü absztraktjainak nyelvi (és esetenként tartalmi) javításáért Thomas Richersnek és Anu Raunionak szeretnénk köszönetet mondani. A Tér és Társadalom számára az elmúlt évben lektori tevékenységet végző személyekről a szerkesztőségi rendszer segítségével teljes listát kívántunk összeállítani, amennyiben azonban saját hibánkból valakit mégis kihagytunk volna, kérjük, jelezze a szerkesztőség számára. 
2014. január és december között lektoraink voltak:

Barta Györgyi
Barta Judit
Bartholy Judit
Beluszky Pál
Bugovics Zoltán
Czirfusz Márton
Csanádi Mária
Csatári Bálint
Csizmadia Zoltán
Csizmady Adrienne
Egedy Tamás
Egyed Ildikó
Erőss Ágnes
Fabók Márton
Faragó László
Fertő Imre
Finta István
Fleischer Tamás
Földi Zsuzsa
G. Fekete Éva
Gábrity Molnár Irén

Barta Györgyi

Barta Judit

Bartholy Judit

Beluszky Pál

Bugovics Zoltán

Czirfusz Márton

Csanádi Mária

Csatári Bálint

Csizmady Adrienne

Egedy Tamás

Egyed Ildikó

Erőss Ágnes

Fabók Márton

Faragó László

Fertő Imre

Finta István

Fleischer Tamás

G. Fekete Éva

Gábrity Molnár Irén
Gál Zoltán

Hajdú Zoltán

Horváth Gyula

Inzelt Annamária

Jakobi Ákos

Jankó Ferenc

Káposzta József

Kiss János Péter

Koós Bálint

Kőszegi Margit

Kuttor Dániel

Lőcsei Hajnalka

Lukovics Miklós

Lux Gábor

Mezei Katalin

Michalkó Gábor

Mógor Judit

Molnár Ernő

Nagy Gábor

Nagy Imre

Nemes Nagy József
Ongjerth Richárd

Ozsvald Éva

Perger Éva

Pósfai Zsuzsanna

Ságvári Bence

Semjén András

Sikos T. Tamás

Somlyódyné Pfeil Edit

Suvák Andrea

Szabó Linda

Szalavetz Andrea

Szerb László

Szokolay Örs

Tagai Gergely

Tamandl László

Timár Judit

Tiner Tibor

Tóth Balázs István

Tóth Géza

Tózsa István

Törőcsik Mária 
$\frac{1}{2}$ 